展 望

\title{
発達的観点よりみた斜線効果現象
}

\author{
橋 本 憲尚* 加藤義 信** \\ OBLIQUE EFFECT FROM A DEVELOPMENTAL POINT OF VIEW
}

Norihisa HASHImoto AND Yoshinobu Kato

\begin{abstract}
Summary: It is well-known that younger children up to the age of about 6 yr. have much difficulty in discrimination between oblique lines in contrast with relative ease in that between horizontal and vertical. This phenomenon is called "oblique effect" and a large amount of studies were conducted over the past twenty years for determining the causes of such effect. This paper reviewed these experimental studies in terms of the development of the children's strategies in encoding and storing information of oblique orientation in memory. Some recent infant studies revealed that even a baby might have his/her categorical ability of orientation, so, during early childhood, the orientational categories should be much elaborated, and several encoding strategies for non-specific orientation such as oblique should be developed in an appropriate way to each stimulus context. This course of the development seemed to be confirmed on the whole from the present overview of the studies concerned. This confirmation afforded a basis for further discussions on a developmental hierarchy in orientational categories.

Key words : oblique effect, encoding strategies, orientational categories, development.
\end{abstract}

垂直あるいは水平に対し，斜めの方位 (orientation) が 生活体にとって異なる心理学的意味を持っことは, 古く から知られてきた。既に前世紀末, Jastrow (1893) は, 様々な方位の線分を視覚的に提示しそれを再現させると， 垂直ないし水平の線分に比較し斜め線分の方位の再生は その正確さにおいて劣ることを報告している。Appelle (1972）は，生活体の斜め方位の刺激へのパフォーマンス が一般に垂直, 水平に比べて劣るという事実を斜線効果 (oblique effect) と名付け, 従来の研究を概観する中で, 人間抢よび動物において視覚に関係する領域（視力, 静 止絧膜像の消失, 錯視, 刺激方位の再生, 刺激方位弁別等) で 広くこの現象が認められることを指摘した。発達的観点 からは, Sutherland (1957，1958，1960) によるタコの方 位弁別学習実験に刺激されて, Rudel \& Teuber (1963) が, 3 歳半から 8 歳半までの子どもにおいて斜線を含む 方位弁別学習の実験を行い，これがその後の子どもにお

*, ** 高知大学 (Faculty of Education, Kochi University)
ける斜線効果研究の発端となった。

本稿では, 斜線効果と呼ばれる現象に発達的視点から アプローチした研究を概観し, 現在の研究の到達点と今 後の研究の方向を明らかにすることを目的とする。“発 達的視点から”という限定は, 斜線効果の名のもとに包 括されている現象の全てが, 本稿の検討の対象となるわ けではないことを意味する。論を進めるにあたって, ま ずこの点をあらかじめ明らかにしておきたい。

Appelle (1972) が命名した斜線効果のらちには, 実は 性質を異にする 2 種類の現象が含まれていると考えられ る。Essock (1980) は, 斜め方位に関するパフォーマン スを処理の水準の違いといら観点から次のような 2 種類 に分類している。それによると, まず第一種は, 視力な ど視覚系の基本的機能を測定する実験パラダイムにおい て観測される斜線効果で, 斜め刺激そのものの検出 (detection) が垂直・水平方位の刺激の検出に比べ劣る事実 に関係する。これに対して, 第二種は, 刺激情報のより 高次の処理を必要とすると考えられる実験パラダイムで 
得られる斜線効果で，具体的には，何等かの記憶負荷を 伴う課題において斜め刺激どうしの弁別や分類が他の方 位閒のそれに比して困難である事実に関係する。

ところで, 視覚系の基本的機能の多くについてはその 生理的対件を探る研究が比皎的進んでいるとともに, 近 年著しい発展を逐げた乳児の知覚研究によって, それら は生後閒もなくから比較的高い水準で備わっていること が知られている。第一種の斜線効果についても，その生 理的基礎を明らかにしようとする試みは既に行われてお り (Rose \& Blakemore, 1974 など), また, 大人と類似の 効果が乳児において観察されたとする報告もある。たと えば, Leehey, Moskowitz-Cook, Brill \& Held (1975) は，大人と同様，6〜50週の乳児の斜め刺激に対する視 力が垂值，水平刺激に対する視力よりも劣るという事実 を報告している。このことから，第一種の斜線効果は発 達的な変化を被ることの少ない現象であると推定される。 これに対し第二種の斜線効果の場合には, 認知, 記憶を 含む高次の処理水準の関与が問題となるため, 年齡に伴 うなんらかの発達的な変化が予測される。事実, 成人と 子どもとの間に著しいパフォーマンスの違いが報告され, 子どもに頙著に観察される効果を規定している要因の研 究が谁んでいるのは，この第二種の斜線効果であり，従 って, 以下, 本稿の検討の対象はこの第二種の斜線効果 に関する発達的研究に限定される。

な㧍，第一種の斜線効果を中心とする研究の概観とし ては，既に Appelle (1972) の論文がある。また新しく は, Rudel (1982) が第一種, 第二種の斜線効果に関す る研究を共に含む展望を書いているが，彼女の場合には Essock の提起したような分類が意識されておらず，も っぱら一種, 二種の区分なく斜線効果の生理学的メカ二 ズムに発生的視点からせまろうとする意図が強い。本稿 はこれら 2 つ概観とは異なって, 高次の情報処理過程 に関係する斜線効果の発達的問題に限定して独自の整理 を試みる。

\section{1. 子どもにとってなぜ斜線弁別が困難か}

子どもの図形や文字の方向認知に関する研究は比較的 古くから行われてきたが (Davidson, 1935 ; 勝井, 1971; 田 中，1966), 後に斜線効果と呼ばれるようになる斜め刺激 どうしの弁別の困難さ, 斜为配列の対象の再生の困難さ (Olson, 1970 ; Piaget \& Inhelder, 1948), 斜为線分の描画 再生の困難さ (Berman, 1976) など, 子どもの斜め刺激へ のパフォーマンスに特に焦点を当てて研究が行われるよ うになったのはそんなに古いことではない。特に，斜め 刺激どうしの弁別の問題は1960年代以降, 系統的に問題
とされるようになった。

この分野の先駆的な研究としては, まず, Rudel \& Teuber (1963) の研究が挙げられる。彼らは 3 歳半から 8 歳半までの子どもに垂直と水平の線分どうし, 斜め線 分どうし (鏡咉的関係にある) の 2 つを含む 4 つの弁別学 習を行わせたところ, 斜め線分どうしの弁別学習に子ど もは著しい困難を示すことを見いだした。特に，年少の 幼児でこの傾向は顕著であった。Rudel \& Teuber は, この事実を発達途上の子どもの視覚系に固有なメカニズ ムに由来する問題として捉え, Sutherland (1957, 1958, 1960）の軟体動物を被験体とする実験において見いださ れた同様の事実を念頭におきながら，視覚系の生理学的 メカニズム解明に資する発生的な視点からのデータの 1 つとして彼らの実験結果を位置付けた。しかし, 既に Essock (1980) の分類を参照すれば明らかなように, Rudel \& Teuber の用いた弁別学習事態は, 視覚系の 基本的メカニズムにのみ由来する子どものパフォーマン スを見る事態とは言いがたい。彼らの実験では, 各刺激 カードは 1 枚ずつ提示され, 被験児はその都度, そのカ 一ドが “正しい”カードであるか“間違っている”カー ドであるか判断を求められる。反応の正否については, 直後にフィードバックが与えられる。被験児は, できる だけ少ない試行数で, 提示される刺激に応じて一貫した 反応をするよう，学習しなければならない。そこでは， 前試行における刺激の方位と実験者によって与えられる 正否の情報の記憶が不可欠である。従って, 前試行の刺 激と次の試行のそれとは異なる方位の刺激に対し同一の 反応が生じたからといって，2つの刺激が視覚系に同一 の知覚的インプットを生じさせているとは限らないこと になる。

Rudel \& Teuber に続く, 子どもにおける斜線効果 研究の初期にまず問題となったのは, 斜線閒弁別の困難 が主に心理過程のどのような処理水準の関与によって生 じているかという問題であった。この点を確かめるため, Over (1967) は弁別学習の技法に代えて, 知覚的処理水 準に依存して課題解決が可能な検出 (detection) 課題 (2 つの同一刺激と 1 つのそれとは異なる刺激を同時に提示して, 異なる刺激の選択に対して強化が与えられる課題)の採用を提 起し，この提起に沿って, Over \& Over (1967) は, 4 歳児と 6 歳児において, Rudel \& Teuber の用いた弁 別学習課題に類似した課題での線分の方位弁別の成績と, 検出課題での成績を比較した。それによると, 弁別学習 課題では Rudel \& Teuber の実験と同様, 斜線間弁別 が困難であったが，検出課題では特に 6 歳児は斜線どう しを垂直一水平と同じように容易に弁別できた。 
Bryant (1969，1973) \& Over と同様の問題関心から, 刺激の方位の記憶が必要な継時マッチング課題と, 標準 刺激と比較刺激の知覚的照合のみが要求される同時マッ チング課題の両方で, 幼児の線分の方位弁別の成績がど のように異なるかを調べた。その結果, 継時マッチング の場合，4歳児，5歳児は斜線間の弁別が困難であるが， 同時マッチングでは垂直一水平弁別と変わらずに容易で あることが明らかとなった。以上はいずれも正方形カー ド内に描かれた刺激線分間の弁別という事態で得られた 結果だが，刺激線分に視的枠組を与えないよう工夫した 装置を用いても，Bryant の実験と同様な斜線間弁別に 関する継時マッチングと同時マッチングの成績差が見い だされている (Harris, Le Tendre, \& Bishop, 1974)。

Bryant と同様の実験事態を用いて, 異なる結果を報 告している研究としては, Schaffer (1974) がある。そ の報告では, 斜線間弁別は同時マッチングにおいても継 時マッチングの場合と同様, 困難であった。Schafferの

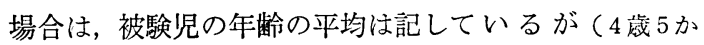
月）その範囲を明示していないこと, 実験者が多数に及 んだと推定され, 各被験児に対してとられた手繶の一定 性に疑問を投げかけることもできるなど, Bryant の結 果と単純に比較できない要素を含んでいる。

以上, データに不一致な点を一部残すが, 初期の研究 は, 幼児における斜線間弁別の困難が弁別学習や継時マ ッチングなど記憶負荷の比較的高い課題でのみ現れるこ とを明らかにしたと言えよう。そうであるならば，この 事実を Rudel \& Teuber のように視覚系に同一の知覚 的インプットが生じてしまうためとして説明することは できなくなる。問題はむしろ, 傾斜角度や傾斜方向を異 にする斜め線分が子どもによって相互にどのように異な るものとして符号化され記憶されるのかという水準にあ ると思われる。

近年, 乳児研究の進展にともなって, 方位弁別能力の 测定が生後間もない時期から可能になってきたが, 斜線 間弁別に関して得られた乳児のデータも，基本的にはそ の問題が, 幼児と同栐, 純粋に知覚的な課題において生 ずるのではなく，なんらかの記憶負荷を要する課題にお いて現れることを示している。

乳児の方位弁別能力は通常, 馴化一脱㓭化の実験パラ ダイム (habituation-dishabituation paradigm) によって測 定される。そこではまず, ある方位の刺激を繰り返し提 示することによってその刺激に対する馿化 (通常, 注視 時間の減少が指標となる) をおこさせ，その後新奇刺激を 導入して, この刺激に対して脱馴化が生じ, 前の刺激に 対して馿化が持続すれば, 両刺激は弁別されたと解釈さ
れる。ここで注意すべきは，この技法と並び乳览の視覚 研究で最もよく用いられる選好注視法 (preferential looking technique ; 対にして提示される2つの刺激パターンへの選 択的注視を測定与る方法）との基本的な違いである。前者 では，馿化が生ずるために反復刺激パターンのなんらか の特性に対する視覚的記憶 (visual memory) が必要であ るのに対し(鹿取, 1984), 後者では同時に提示される 2 刺激への提示中の注視だけが問题となるから, 刺激に対 する視覚的記憶の必要はない。

上述の馿化一脱馴化実験パラダイムによって，まず， Weiner \& Kagan (1976) が 5 か月児で $35^{\circ}$ 斜めと水平線 分の弁別可能を確認し, 続いて Bornstein, Gross \& Wolf (1978) が 4 か月児で $45^{\circ}$ 斜めと重直線分の弁別可 能を確かめた。Bornstein et al. はさらに，4 か月児は 右 $20^{\circ}$ 斜めと右 $70^{\circ}$ 斜め線分の弁別が可能であったことも 報告している。それより月齢の低い乳児では, Maurer \& Martelle (1980) が $5 \sim 6$ 週児で鏡映像斜め弁別(格 子縞パターン) が可能であったと報告している。しかし, 馴化一脱馴化パラダイムとオペラント条件づけの手法を 組合わせた吸啜反応法 (High-amplitude sucking paradigm) による 2 か月览の鏡映像斜め弁別の実験では，肯定的な 結果は得られなかった (Essock \& Siqueland, 1981)。彼ら の用いた吸啜反応法は, Maurer \& Martelleの用いた 標準的な馿化一脱馿化の実験手法に比べ一層手続が複雑 で，乳児は単に方位という刺激関連次元への注意や処理， その想起を行えばよいだけでなく，刺激の出現と吸啜反 応との間の随伴性を発見しそれを想起しなければならな い。このような学習の必要性とより大きな記憶負荷が, おそらくEssock らの実験における結果を Maurer \& Martelle の結果とは異なるものにしたと考えられる。

記憶負荷の大小を変数として導入し, 乳児の斜为刺激 どうしの弁別について検討しているのは, Quinn, Siqueland \& Bomba (1985) である。彼らは, 馴化後の弁別 テストを直後に行った場合と 3 分後に行った場合の 2 条 件を設け， 2 か月児と 3 か月児による垂直一水平刺激対 及び斜め刺激対の弁別を調べた。それによると，水平一 垂直刺激対では直後, 遅延の両テスト条件でともに弁別 が行われている証拠が得られたが, 斜め刺激対の場合は 直後テスト条件でのみ弁別が可能で, 遅延条件では弁別 できなかった。つまり, 馴化後, 斜め刺激の特定の傾き に関する情報の記憶は非常に短時開しか保持されず，時 間とともに急速に消失することが明らかとなった。この 結果は, 以下の Bomba (1984) や Quinn \& Bornba (1986) の結果と合わせ考えると大変興味深い。

Bomba は， 4 か月児に $6^{\circ}$ の範囲内で変化する斜め刺 
激（例光ば傾き $22.5^{\circ} \pm 3^{\circ}$ の間の刺激）に対して馴化を生じ させた後, テスト試行においてこれとは異なる傾きの斜 め刺激 $\left(45^{\circ}\right)$ と垂直刺激を対提示すると, 後者一の有意 な注視がおこることを示した。この選好は，45の斜め 刺激と馴化を生じた $22.5^{\circ} \pm 3^{\circ}$ の斜め刺激が同一の刺激 と解釈されるのに対し，垂直刺激はこれとは別な新奇刺 激として招えられるた为に生じたと考えられる。Bomba

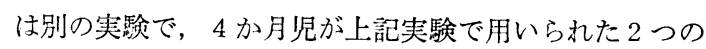
斜的刺激 $\left(22.5^{\circ}\right.$ と $\left.45^{\circ}\right)$ を乎別できることを示しているの でこの結果は，4か月児が，弁別可能な傾きの異なる 斜め刺激を型直刺激に対しては同じカテゴリーの刺激と して扱いうる能力を持つことを示唆している。Quinn \& Bomba もほぼ同様な手続を用いて，4 か月児では，垂 直軸を狭んで左右に異なる方位の斜め刺激が垂直とは異 なる同じ刺激として反応される傾向があると報告してい る。

この 2 つの研究と Quinn et al. (1985) の結果の意味 は, 次のような点にあると考えられる。即ち, 刺激の方 位に関する情報の記憶保持に法おそらく階層性があって, 個々の刺激の特定の傾きに関する情報は非常に短時間で 消失してしまうのに対し，特定の方位の刺激がどの方位 に関するカテゴリーに属しているかという情報は, 比較 的長く保持が可能であると思われる。このような方位に 関する情報の記憶保持の階層性は, 遅くとも生後 4 か月 の時点で既に存在しており, この時期には, 斜めは垂直, 水平に対して 1 つのカテゴリーを構成している。このよ らに考えると，記憶負荷の小さい事態では乳児でも斜め どうしの弁別が可能であるのに，記憶負荷の大きい事態 では，幼児期になっても依然としてそれが難しいという 事実との関連が一層はっきりしてくるように思われる。 おそらく, 幼児でも, 記憶負荷の大きい継時弁別条件下 では, 異なる斜め刺激は同一のカテゴリーに属する刺激 として処理され，そのようなカテゴリー水準の情報の記 憶に主に頼って反応が行われるため, 斜めどうし弁別は 依然しして困難なのであらう。従って, 幼児期から児童 期にかけてこのような弁別が記憶負荷の高い事態でも可 能になっていく過程は, 斜め方位内のカテゴリーの分化, ないしは比較的長い記憶保持に必要な新しい符号化の方 法を獲得する過程として記述できる可能性がある。以下， 本稿で試みる幼児期の斜線効果研究の整理は, このよう な観点からのものである。

\section{2. 幼児による斜線弁別の方略}

\section{（1）外的基準との関係の符号化}

幼児にとって記憶にかかわる斜線弁別は困難であると
いう現象については, 弁別課題場面に扝いて幼坚が使用 する符号化方略を推定することにより具体的に考察を深 めていくことができる。このような方略関する仮説と して Bryant $(1973,1974)$ によりッチ・ミスマッチ符 号 (match-mismatch code) 仮説, Fisher (1980)により限 定符号 (restricted code) 仮説が提唱された。いずれも幼 児は線分方位を刺激布置内の手掛りとの相対的関係でも って符号化すると想定している点では共通しているが， 前者では線分と手掛りとの平行関你, 後者では線分の傾 斜方向と手掛りとの位置関係が処理されると想定してい る。すなわち, 斜線弁別の問題が垂直一水平ならぬ “斜 め”であることの符号化にあるか，左あるいは右のいず れかに傾いているかといら傾斜方向の符号化にあると考 えるかの点で異なるといえよう。

(A)マッチ・ミスマッチ符号仮説

Bryant は, 幼児の斜線マッチングパフォーマンスが 継時条件でのみ垂值一水平線分間より劣ることを以下の ように説明する。標準刺激と比較刺激対が同時に提示さ れる同時条件では, 後者が前者と平行か否かを検出する だけで十分であるのに対し, 標準刺激提示終了後に比較 刺激対が提示される継時条件では，まず刺激布置内にあ る手掛り線分（例总ば，刺激カード地部屋の縁）と前者の平 行関係を処理しておき, 続いてその手掛り線分と後者の 平行関係を処理して各々の結果を照合しなくてはならな い。ところが, 通常の実験場面での視的枠組を構成する 手掛り線分は垂直または水平であるため, 垂直一水平線 分弁別では比較刺激の必ず一方は手掛り線分にマッチ, 他方はミスマッチとなるが，斜線弁別では比較刺激のい ずれもミスマッチとなるため弁別困難となる。

この仮説が正しいとすれば，継時マッチングでも標準 刺激と平行な手掛り線分が恒常的に提示されている状況 では，斜線弁別は容易になるはずである。Bryant (1969, 実験 2 ) は正方形の左右 2 辺, ひし形の上 2 辺の一方を

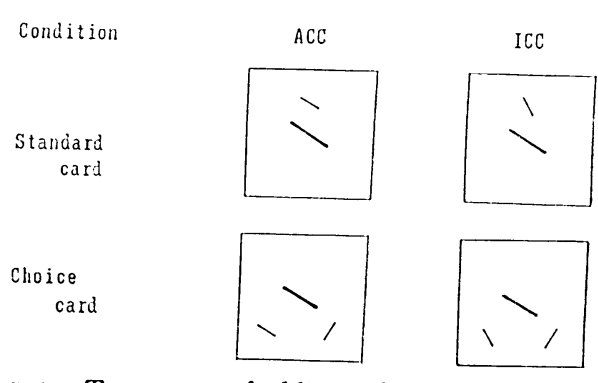

FIG. 1 Two types of oblique discrimination display with thick line parallel (ACC), or non-parallel (ICC) to standard line. (adapted from Bryant, 1973, 1974) 
赤, 他方を青に塗り分け, 各々の枠内に刺激提示した場 合を比較し, ひし形枠組の条件でのみ鏡映斜線弁別が促 進されることを見いだした。さらに Bryant (1973, 実験 2) では, 試行中, 常に選択肢の一方と平行な斜線（赤 色，3 倍の太さ）が提示されている条件 (ACC) では, 選 択肢のいずれとも平行でない斜線が提示されている条件 (ICC), 及び手掛りとなるような斜線が全く提示されて いない条件より斜線弁別が良好であることが示された (FIG.1参照)。また，この仮説に従うと，通常の提示条 件では手掛りとなる線分は水平もしくは垂直でしかない ので, どんな斜線も手掛り線分に対してはミスマッチと なる，それ故，比較刺激対がいずれも斜線でありさえす れば鏡映であろうとなかろうとそれらの弁別は同様に困 難であるはずだと説明できる。実際, Bryant の研究で は，鏡映でない斜線弁別も鏡映斜線弁別と同様に困難で あることが示されただけでなく，前述の適切な手掛り斜 線の提示効果がいずれの斜線弁別にも等しく認められた。

ところが，その後の研究では手掛り線分の提示効果は 認められなかった。Fellows \& Brooks (1973) では正方 形，ひし形のいずれの枠組提示条件でも鏡映斜線弁別は 困難であり，手掛り線分を色づける・しないによる影 響も見られなかったという。Williamson \& McKenzie (1979, 実験 1 と 2) は刺激と手掛り斜線を色分けして円筒 内に提示したが, 手掛り線分が比較刺激対の一方と平行, いずれとも平行でないの 2 条件における斜線弁別に差は 見いだされなかったと報告している。

Fellows \& Brooks は 幼児がマッチ・ミスマッチの 符号化を自発的に行うことはないと主張し，Bryantの 実験では教示において視的枠組に注目させるような何等 かの示唆が行われたのではないかと推察している。また, もし幼児が視的枠組を構成する手抾り線分との平行関係 で刺激線分の方位を符号化するのなら, 垂直または水平 線と斜線の弁別は提示される枠組が円形であれば正方形 の場合より困難になるはずだが, Berman \& Cunningham (1977) は全く逆の結果を得ている。したがって, マッチ・ミスマッチの符号化は線分方位弁別に際して幼 児が使用しうるひとつの方略にすぎないといえるであろ 亏。

(B)限定符号仮説

Bryant の実験では, 比較 2 斜線の傾斜方向は必ず異 なっていたので，いずれか一方の斜線と平行な手掛り線 分の提示効果があったとしても，それは幼児が斜線閒の 平行関係を符号化できたからではなく, 斜線の傾斜方向 を符号化しやすくなったためかもしれない。

刺激布㯰が上下，左右の各次元に関して全く対称的な
環境は通常ありえない。Thompson (1975) は，幼児は図 形の垂直もしくは水平中心線からみて, 方位弁別に関連 する示差的図形特徴 (例光ば, 三角形の頂角) が, 背景の 片側のみに常に存在する手掛り特徵（例觉ば，実験室の空， 実験器具) と同じ側にあるか否かを符号化するのではな いかと考えた。彼は, 6 歳児による上下反転・左右反転 (鏡映) 図形の弁別学習の相対的難易差が刺激提示条件に より異なることを見いだしたが，彼の仮説に従って左右 反転図形の弁別を説明すると，比較別激が垂直上下に対 提示された場合 (同時に提示された 2 刺激のうち “正しい”方 を推測する) や単独提示された場合（継時的に提示される各 各の刺激に対して “正しい”か否かを推測する)には，刺激の 示差的図形特徴が布置内の左右位置の手掛りとなる特徵 と同じ側にあるか否かを容易に検出できるが，水平左右 に対提示されると, 一方の図形と手掛り特徵との間に他 方の図形が介入するため, 検出が困難となる故に弁別が 難しくなるという。

Fisher（1980）のいう限定符号仮説は，上述の反転図 形弁別に関するThompson の仮説をもとに斜線弁別に おける幼児の方略を論じたもののようである。幼児は, 線分と刺激布置内の近接する手掛り特徵との位置関係を 符号化することにより線分の方位を記憶する。ところが， その符号はある特定の刺激布置内における非常に限定さ れた空間関係を表わすにすぎず, 線分と手掛り特徴との 位置関係が変動すると弁別は困難になるという。彼女は, $5 \sim 6$ 歲児による鏡映斜線弁別学習が, Thompson が 反転図形弁別で見いだしたのと同様，単独提示条件での 方が水平左右に対提示した条件より容易であることを確 認し (実験 1), さらに単独提示条件であっても通常と暴 なり提示カード枠内の位置が試行毎に変化する場合には 困難となることを見いだした（実験 2)。例えば，右上が

CONSTANT SUCCESSIVE SUCCESSIVE VARIED

SIMULTANEOUS
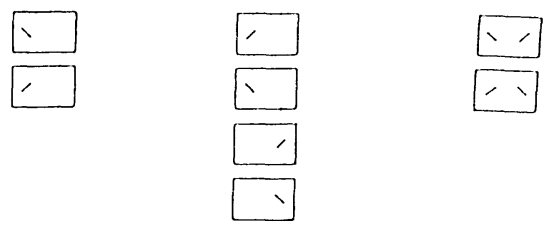

FIG. 2 Three types of oblique discrimination display. In the first (constant successive), each of lines were presented successively in a fixed position, in the second (successive varied), each of lines presented successively changing position from trial to trial, and the last (simultaneous), a pair of lines presented simultaneously. (Fisher, 1980) 
りの斜線は提示される位㯰が一定しておれば，その上部 が常に枠の “中心を指している”あるいは“中心から離 れた方を指している”のいずれかとして同定できるが， 提示位置が左右に変動すれば，あるときは“中心を指し ている”，あるときは“離れた方を指している”と同定さ れるので再認困難になるというわけである。(以上, FIG. 2 参照)

\section{（2）身体基準系に依拠した斜線弁別}

前述のいずれの仮説においても，幼児は線分方位を視 的枠組内の手掛りとの相対的関係に基づいて符号化する と仮定されている。Bryant (1974) は，このような幼児 の図形方位弁別の方略を，相対的符号化から絶対的符号 化へという認知発達過程にみられる過渡的性格をもつ方 略と位置づけている。幼児期には, 対象と同時に提示さ れている手脚りとの直接比較によってのみ方位判断が可 能であり, 自らの身体基準系によって対象の方位が垂直, 水平, 斜めのいずれかといった絶対的なカテゴリー化を 行うことはできない。それ故, 継時的に提示された対象 間の比較判断は, 前述のいずれの仮説においても主張さ れていたように, 常に刺激布置内に存在する手掛りと対 象との関係を検出しておき, それら検出結果に基づいて 行われるのだという。

それでは，刺激布置内に手掛りがない状況では，線分 方位弁別は幼児にとって困難であるのだろうか。Fisher (1979) によると $3 \sim 4$ 歳児に円形空枠から刺激をのぞか せて単独提示条件で弁別学習課題を与えた場合には，垂 直一水平線弁別，鏡映斜線弁別の難易差はなかったが， その後同じ被験者を用いてテーブル上に水平左右に対提 示する手続で実験したところ，斜線弁別がより困難であ ったという。つまり，年少児であっても自己身体基準系 に依る斜めの符号化が可能であるのだが，刺激布置内に 込み入った空間関係情報がもちこまれた状況では混乱し てしまうのである。

次に，幼児の斜線弁別パフォーマンスに影響を及ぼす 刺激布㯰内の空間情報の性質について考察しておこう。 Fisher \& Heincke (1982) によると弁別学習課題 (円筒 内に線分のみを提示) において水平左右対提示条件でのパ フォーマンスが単独提示条件より劣るのは傾斜方向のみ が異なる斜線，つまり鏡映斜線弁別のみであり，傾斜角 度のみが異なる斜線弁別では両条件ともにパフォーマン スが良好であったという。また，Fisher (1982) は，対 提示条件での弁別学習に 2 線分の配置効果を見いだした。 通常 2 斜線は垂直軸に関して対称的に（鏡映像を成すよ ら）配置されるが，非対称的に配置すると垂直一水平線 弁別と同程度にまで容易になったと報告している。しか
ALI GHMENT

SHMMETRICAL

ASYHMERTICAL

VERT ICALHORIZONTAL
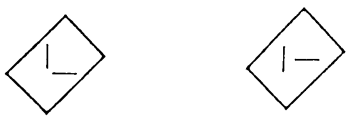

MIRROR-IMAGE OBLIQUE
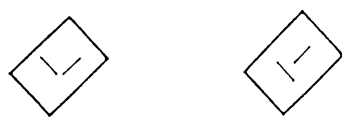

FIG. 3 Vertical-horizontal and mirror-image oblique line discrimination display in symmetrical and asymmetrical alignments. (Fisher, 1982)

も傾斜枠組で刺激対を囲んで対称軸を強調すれば，垂直 一水平線弁別でも対称的配置では斜線弁別と同程度に困 難であったという (FIG. 3 参照)。以上の実験結果を参照 する限り，身体基準系あるいは視的枠組でもって規定さ れる垂直中心線の両側にまたがって弁別すべき 2 刺激が 提示されるとき，斜線弁別に有効に作用する空間情報が 提供されるといえるであろう。

\section{（3）斜線の再生}

斜めの記憶表象について論じるには, 弁別課題よりむ しろ再生課題を取り上げる方が適切であるように思われ る。Olson (1970) は, 斜線配列モデル（マトリクス状に並 んだ丸をいくつか塗りつぶすことによって斜線を示す）をバル ブボード上（モデルに対応するバルブを押した時だけ点灯す る）に再生する（バルブを斜めに正しく押して行く）ことが できなかった $3 \sim 5$ 歳児に対し 2 とおりの教示訓練を行 った。一方の群ではモデルをよくみて点灯するバルブに 対応する丸はどれか指示させた後, ボード上の点灯する バルブだけを正確にすべて押すまで繰り返す（試行錯誤 強化群), 他方では実験者が斜めとはどんなものかを示し, どのようにすれば紙の上で構成できるかを正方形の特性 を利用しながら説明 (例えば,「こっちの角を出て間を横切っ てもらひとつの角までまっすぐ行くんだよ。」）を加える（構造 化学習群) 手続をとった。その結果, 訓練直後の転移課 題 (傾斜方向が反対の斜線の再生) において, 構造化学習群 の大半の幼児が成功したのに比し, 試行錯䛊強化群では ほとんどが失敗したという。また, Goldstein \& Wicklund (1973) は, モデルどおり斜め配列をチェッカーボ 一ド上に再生する課題では, 実験者が単にモデルを構成 するのではなく, チェッカーを置く位置の選択を明示し ながら構成するのを観察させても効果はなかったと報告 している。このように, 再生課題については特定の反応 (バルブを押す，あるいはチェッカーを固く）に関する学習が 効果をもたないことが明らかにされており，子どもがも つ斜めの表象を評定するには優れた課題であるといえよ 
う。

しかし，チェッカーを使っての再生課題ではそれらと モデルとなる線全体との関係を知営的に分析し, 部分か ら全体の形態を再生するという余分な認知負倚を必要と している。そこで斜めの記憶表象についてより撖密に論 ビるには，モデルと同じ方位にひとつの棒を置く課題や モデルと同じ方位の線を描く課題における幼児のパフォ ーマンスを検討する方がより適切だと考えられる。

Mandler \& Stein (1977, 实験 2) によると, $5 \sim 6$ 歳 児にとってこのタイプの課題は継時マッチング課題より 容易であるという。それは抢そらく前述のごとく, 通常 のマッチング課題では刺激提示布置内の空間関倸情報か らの干涉があるからであろう。彼らは，少なくとも5 歳 には斜めの正しい記憶表象が形成されていると結論して いるが，比較的単純と思われるこのような課題において も視的卆組の効果が観察されている。モデルの提示, 再 生䘮長方形デーブル上の正方形カードで行わせた場合で は斜線の再生は垂直・水平線に比して困難であるが, 円 形テーブル上の円形カードで行わせた場合では水平線の 再生も斜線と同程度に困難であったという (Berman, Cunningham \& Harkulich, 1974 ; Berman, 1976)。つまり, 斜線効果は枠組の形態に依存するのである。

ここで注目しておきたいのは, 枠組の形態によって斜 線再生の誤りパタンに違いがある点である。前述の 3 研 究の結果を総合すると, 円形の場合には誤りに一定した 傾向が見られないのに対し，正方形枠あるいは周囲に手 掛りがある場合ではモデルと反対方向に傾斜するよう再 生する率が非常に高い。すなわち, 刺激布置内の何等か の特徴により左右の傾斜方向に関する情報が干渉を受け るわけである。Berman らの実験では記銘, 再生が同じ 視的枠組内で行われたため, 干渉がいずれの過程で生じ るのかは不明である。しかし, 少なくとも幼児は, どの ような刺激析置であっても斜線を重直線や水平線とは異 なるものとして認知していると教えられる。

\section{3. 総插討論}

Olson は, 空間認知の発達を対象のもつ諸特性とそれ らの関係の知覚表象の精繳化, 及び知覚表象のうちに隠 されている空間情報を意識化していくことだと主張して いる (Olson, 1970 ; Olson \& Bialystok, 1982)。彼によると 人類の文化的発明 (言語, 科学, 芸術など) は, 子どもに この意識化の契機を与え, 発達を促すものだという。例 えば斜为に関して言えば, 対角線の概念や遠近画法の修 得は, 我々の “斜め”という心的表象をより明確なもの にするのに役立っているのではないかと推察される。第
一の例面）

他方, 心的表象の操作技能の熟達という側面も見逃せ ない。例えば，将棋やチェスで駒の位固を表現する，あ るいはグラフ用紙に座標嵮を設定して点をプロットして いく場合，明らかにある種の心的操作が必要とされてい る。即ち，各次元における符号を互いに独立した概念的 要素として扱い，それらを等価にあるいはある重みをつ けて結合させねばならない。（第二の测面ここではまず， 第 1 の側面を方位の表象の階層性の観点に牥いて考察す ることから始めよう。

\section{（1）方位表象の階層における “斜め”}

方位表象の階層性に関する図示の試みが, Oison(1970) 及び Braine (1978) に見られる。いずれも，互いに弁別 容易な方位から弁別困難な方位へと階層を重礼ていくよ う図示されている。これらの記述においては上方向・下 方向, 右方向・左方向といった方向性をも考慮されてい るが, 既述のごとく斜線効果に関する研究では通常, 垂 直, 水平との比較のみが問題とされてきた。乳児研究で 明らかにされたように，斜めは生後早い時期で既に垂直， 水平と同列に扱われ得る別のカテゴリーを形成している と考えられる。そして, 幼児期における斜方位表象の 発達の問題は斜めカテゴリー内の分化のしかたにあると 考えられる。そこで以下，幼児による斜線弁別の困難さ の要因についてのこれまでの議諭の展開を整理した上で, 独自の方位表像の階層モデル提示を試みる。

Corballis \& Beale (1976) は, 記憶課題において鏡映 斜線弁別が幼児にとって困難である問題を鏡映像混同に 帰着させた。つまり幼児の生理学的成熟段階においては, 利き手が明確でないことからも推察されるように, 神経 系が内的非対称 (大脳半球の左右㙨能分化浫ど)を生じるま でには発達しておらず，そのために鏡映像混同が生じる ことが原因になっていると推論した。ところが，継時マ ッチング課題に衫ける斜線間混同は鏡映関係になくとも 生じるといら実験結果 (Bryant, 1969, 1973 など) から, 問題は鏡映像混同でなく斜めであることの符号化にある と指摘されてきた。

その後, 傾斜方向, 傾斜侮度を組織的俉作して弁別 の正確さを比較した研究が行われ，斜め注角度と方向と いう 2 要素に分解されて議論されることになった。Williamson \& McKenzie (1979) は, 角度, 方向のいずれ が幼児の斜線弁別により大きく影響しているかを評定す るため, 傾斜方向は同じであるが角度は異なる対, 角度 は同じであるが方向が異なる対 (鏡映斜線対)，方向・角 度のいずれも異なる対の弁別パフォーマンスを比較した。 彼らは自ら得た結果と以前の研究結果とを対照させてい 
TABLE 1 The effects of degree and direction of slope discrimination between oblique lines. (adapted from Williamson \& McKenzie, 1979 TABLE 5)

\begin{tabular}{|c|c|c|c|c|}
\hline & \multicolumn{3}{|c|}{ Combination of oblique lines } & \multirow{2}{*}{$\begin{array}{l}\text { Presentation } \\
\text { of } \\
\text { alternatives }\end{array}$} \\
\hline $\begin{array}{ll} & \begin{array}{l}\text { Direction } \\
\text { Degree } \\
\text { Age }\end{array} \\
\text { Research }\end{array}$ & $\begin{array}{l}\text { Same } \\
\text { Different }\end{array}$ & $\begin{array}{l}\text { Different } \\
\text { Same }\end{array}$ & $\begin{array}{l}\text { Different } \\
\text { Different }\end{array}$ & \\
\hline Successive maching & Mean perce & entage of & errors & \\
\hline \multicolumn{5}{|l|}{ Bryant (1969) Exp. 2} \\
\hline \multirow{2}{*}{\multicolumn{5}{|c|}{$\begin{array}{c}\text { 5yr. } \\
\text { Bryant (1973) Exp. } 1\end{array}$}} \\
\hline & & & & \\
\hline $4,5,6 y{ }^{11}$ & & 42.25 & 41.25 & simultaneous \\
\hline \multicolumn{5}{|l|}{ Corballis \& Zalik (1977) } \\
\hline $4-6 y$ r. & $47,14^{*}$ & 42.86 & $26.43^{*}$ & simultaneous \\
\hline \multicolumn{5}{|c|}{ Williamson \& McKenzie (1979) Exp. 2 \& 4} \\
\hline $5 \mathrm{yr}$ & 43.38 & 47.5 & 43.38 & simultaneous \\
\hline Discrimination learning & \multicolumn{4}{|c|}{ Mean trials to learn (Percentage of failures) } \\
\hline \multicolumn{5}{|c|}{ Fisher \& Heincke (1982) } \\
\hline \multirow[t]{2}{*}{ Exp. $13-4 y r$} & $32.00^{*}$ & $26.06^{*}$ & & successive \\
\hline & $(40.63)$ & $(28.13)$ & & \\
\hline \multirow[t]{2}{*}{ Exp. $23-4 y^{2} .^{2}$} & $9.13^{*}$ & 25.46 & & simultaneous \\
\hline & $\left(\begin{array}{l}0 \\
0\end{array}\right)$ & ( 60$)$ & & \\
\hline
\end{tabular}

\footnotetext{
* between two numbers in the same row indicates a significant differece at $\mathrm{p}<.025$ or greater.

1) average percentages among three age groupes calculated by authors.

2) subjects succeeded in both tasks in Exp. 1 .
}

るが, TABLE 1 は彼らが作成した表に基づいてより多く の実験結果ををとめたものである。ただし，各実験結果 から推論された斜めの符号化の困難さの要因は, 傾斜角 度と方向の相互作用 (Corballis \& Zalik, 1977), 斜めであ ること (Williamson \& McKenzie, 1979, 実験 2 と 4), 選択 肢を並列提示した場合に限り傾斜方向 (Fisher \& Heincke, 1982)，とまちまちであった。以上のように議論の焦点 は, 傾斜方向もしくは傾斜角度のいずれの基準でもって 斜め内部のカテゴリー化が進むのかにあった。このこと を踏まえた上で方位表象の階層モデルを描いたものが FIG.4 である。まず, 斜めは垂直, 水平以外の方位とし て認知され，斜めどうしは左右の傾斜方向もしくは勾配 の大小でもって弁別される。尚, 図中の言語ラベルは分 化のしかたをより明確にするためのものであって, 決し て表象の分化がラベルの成立に依存して生じることを示 唆するわけではない。

ところで，幼児による斜線弁別の方略として提唱され てきたのは, このカテゴリーの分化基準であるといえな いだろうか。マッチ・ミスマッチ符号仮説に抢いては傾 斜角度の符号化, 限定符号仮説においては傾斜方向の符 号化が斜線弁別に有効作用すると考えられているよう に思われる。しかしながら，TABLE 1 を概観したところ では, 幼児は斜線のうちに幾つかの種類があることに気 ゔいているのだろらが，それらの違いを傾斜方向，角度 のいずれに基づいて符号化するかについては確定的でな
い。おそらく, 刺激布置全体がもたらす空間情報, 刺激 提示の文脈などによって幼児の符号化方略は変動するの であろう。FIG.4 において, 斜線の表象分化が実線によ って示されていないのはそのためである。上述の点をよ り明確にするための今後の 1 つの研究方向として, 種々 の提示状況における学習訓練結果の分析（例总ば, Jeffrey, 1966）を期待したい。

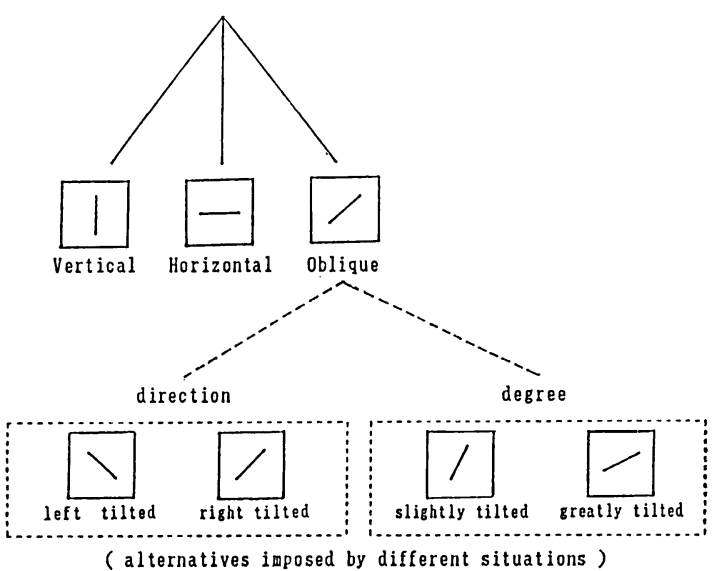

FIG. 4 A proposal on hierarchical structure of representation of line orientation. (Verbal labels here are used only for indicating each of orientations, not for indicating children's actually acquired labels.) 


\section{（2）心的交象の操作技能の問題}

次に, 心的表象の操作技能の熟達という空間認知発達 の第 2 の側面について考察しょう。これまで本稿で取り 上げてきた斜線弁別，再生に関する従来の研究は，専ら 幼児の斜めの符号化形式を探求するものであった。しか し，近年，斜線効果を表象の操作の観点から説明しょう という試みが散見されるようになった。Olson \& Bialystok（1983） は刺激の同一性判断が正確に行われるため には, 2 分法的 “真偽指標” (binary logical "truth index”) 形式の符号の結合が必要であると主張する。例えば， 2 本の $45^{\circ}$ 斜め線分をひとつの大きな正方形の枠内に提示 した場合，それらの提示位置及び傾斜方向の各々を枠の 同じ対角線上にあるか否かによって符号化する。そして， 2 つの符号の真偽が一致しているなら 2 斜線は同じ，一 致していなければ異なると反応寸れば常に正答に導かれ るという。しかし，幼児にとってはこうした符合化は可 能であっても，符合を結合させて 2 重論理に従って反応 を決定する操作は困難であるのではないかと推測されて いる。

Olson たちの考えとは少し異なるが, Frye, Clark, Watt \& Watkins (1986) も論理的操作の発達という観 点から斜線効果を説明しょらとしている。彼らは, 幼児 にとって斜めの再生が困難であるのは, 上下・左右の 2 つの次元に関する情報を協応させなくてはならないこと によると考え，手元のボタン入力によってコンピュータ ・ディスプレイ上に斜線を描く課題を考案した。通常の ディスプレイ・入力装置条件で斜線を描くには，上下方 向及び左右方向のボタンを押してから確定させる手続を とらなければならないが, ディスプレイ・入力装置を $45^{\circ}$ 回転させた条件では，斜めはひとつのボタン操作で描け ることになる。その結果, 通常装置条件では垂植・水平 線より斜線の方が困難であったのに対し，回転装置条件 ではその難易が逆転 ( 5 歳児)，あるいは難易差がなかっ た（8䠞児）と報告している。この研究ではボタン操作 を表象の操作に対応ゔけているが，今後，斜めを扱った 種々の課題について表象の操作性の問題を詳しく検討し なくてはならないであろう。

以上， 2 つの側面を個別に取り上げて䜊じたが，これ らが錯綜した形で発達が進行していくものと想定される。 元来, “斜め” は日常場面においては問題にされること は少なく，その心的表象は自然発生的に獲得されていく ものではない。それ故，傾斜方向，觕度のいずれをもっ て弁別が行われやすいかは確定せず，課題解決のために は状況に応じた符号化の方略, あるいは構成要素符号の 操作が必要とされるのではなからうか。
斜めの心的表象がもつこのような特性は，現在のとこ ろ十分に明らかにされているとはいいがたい。既述のご とく, 従来の幼児を対象とした研究は斜線の弁別や再生 の難易度の測定に集中して行われてきた。つまり，斜め というカテゴリーが，例えば左斜め，右斜めといった下 位項目に分化している程度が問題とされてきた。しかし ながら, Bornstein (1984) に従うと, 幼児期には諸対象 から複数の次元を超えて共通した特性を抽出する機能, すなわち, 概念的に等価なカテゴリー化 (conceptual equivalence categorization) が発達する。それは斜めの概念に ついて言えば，傾斜方向，角度という 2 つの次元におけ る符号が異なるいくつかの斜線が，斜めであることでも って1つにまとめられることを意味する。例えば，線が どれくらい傾いているかに関係なく左に傾いていること， あるいは左右どちらに傾いていようと傾きが小さいこと に意味がある状況があるだろう。また，ともかく傾いて いる，斜めであることが決定要因である場合もあるかも しれない。このような時, 各々の次元で異なる “斜め” に対し，異なった反応を行うことは環境への適応という 観点から言って效率的であるとは言えないだろう。今後 の研究においては，カテゴリーが下位項目へ分化してい くと同時に，分化したカテゴリー下位項目が容易に統合 されうるといった性質，つまり分化，統合の融通がきく という意味での概念の可塑性 (Strauss \& Lewin, 1981) に 着目すべきであろう。

\section{引用文献}

Applle, S. 1972 Perception and discrimination as a function of stimulus orientation: The oblique effect in man and animals. Psychological Bulletin, 78, 266-278.

Berman, P.W. 1976 Young children's use of the frame of reference in construction of the horizontal, vertical and the oblique. Child Development, 47, 259-263.

Berman, P.W., \& Cunningham, J.G. 1977 Development of ability to discriminate orientation : Learning to use the frame of reference. Developmental Psychology, 13, 545-546.

Berman, P.W., Cunningham, J.G., \& Harkulich, J. 1974 Construction of the horizontal, vertical, and oblique by young children : Failure to find the "oblique effect". Child Derelopment, 45, 474 -478 .

Bomba, P.C. 1984 The development of orientation 
categories between 2 and 4 months of age. Journal of Experimental Child Psychology, 37, 609 -636 .

Bornstein, M.H. 1984 A descriptive taxonomy of psychological categories used by infants. In C. Sophian (Ed.), Origins of cognitive skills. Hillsdale, N.J. : Erlbaum.

Bornstein, M.H., Gross, J., \& Wolf, J. 1978 Perceptual similarity of mirror images in infancy. Cognition, 6, 89-116.

Braine, L.G. 1978 A new slant on orientation perception. American Psychologist, 33, 10-22.

Bryant, P.E. 1969 Perception and memory of the orientation of visually presented lines by children. Nature, 224, 1331-1332.

Bryant, P.E. 1973 Discrimination of mirror-images by young children. Journal of Comparative and Physiological Psychology, 82, 415-425.

Bryant, P.E. 1974 Perception and understanding in young children : An experimental approach. London : Methuen.

Corballis, M.C., \& Beale, I.L. 1976 The psychology of left and right. Hillsdale, N.J. : Erlbaum.

Corballis, M.C., \& Zalik, M.C. 1977 Why do children confuse mirror-image obliques? Journal of Experimental Child Psychology, 24, 516-523.

Davidson, H.P. 1935 A study of the confusing letters b, d, p, q. Journal of Genetic Psychology, 47, 458-468.

Essock, E.A. 1980 The oblique effects of stimulus identification considered with respect to two classes of oblique effects. Perception, 9, 37-46.

Essock, E.A., \& Siqueland, E.R. 1981 Discrimination of orientation by human infants. Perception, 10, 245-253.

Fellows, B.J., \& Brooks, B. 1973 An investigation of the role of matching and mismatching frameworks upon the discrimination of differently oriented line stimuli in young children. Journal of Child Psychology and Psychiatry, 14, 293-299.

Fisher, C.B. 1979 Children's memory for orientation in the absence of external cues. Child Development, 50, 1088-1092.

Fisher, C.B. 1980 Children's memory for line orientation: A reexamination of the "oblique ef- fect". Journal of Experimental Child Psychology, 29, 446-459.

Fisher, C.B. 1982 The role of stimulus alignment in children's memory for line orientation. Child Development, 53, 1070-1074.

Fisher, C.B., \& Heincke, S. 1982 Children's memory for oblique orientation : A matter of degree? Child Development, 53, 235-238.

Frye, D., Clark, A., Watt, D., \& Watkins, C. 1986 Children's construction of horizontals, verticals and diagonals : An operational explanation of the "oblique effect". Developmental Psychology, 22, 213-217.

Goldstein, D.M., \& Wicklund, D.A. 1973 The acquisition of the diagonal concept. Child Development, 44, 210-213.

Harris, P.G., Le Tendre, J.B., \& Bishop, A. 1974 The young child's discrimination of obliques. Perception, 3, 261-265.

J astrow, J. 1893 On the judgment of angles and positions of lines. American Journal of Psycho$\log y, 5,214-248$.

Jeffrey, W.E. 1966 Discrimination of oblique lines by children. Journal of Comparative and Physiological Psychology, 62, 154-156.

鹿取廣人 1984 現代基礎心理学10 発達 2 個体発生 第 3 章 感覚, 知覚 東京大学出版会

勝井 晃 1971 方向の認知に関する発達的研究 風間 著房

Leehey, S.C., Moskowitz-Cook, A., Brill, S., \& Held, R. 1975 Orientational anisotropy in infant vision. Science, 190, 900-901.

Mandler, J.M., \& Stein, N.L. 1977 Encoding and retrieval of orientation : A new slant on an old problem. Bulletin of the Psychonomic Society, 10, 9-12.

Maurer, D., \& Martelle, M. 1980 The discrimination of orientation by human infants. Vision Research, 20, 201-204.

Olson, D. R. 1970 Cognitive development: The child's acquisition of diagonality. New York: Academic.

Olson, D.R., \& Bialystok, E. 1982 Spatial cognition : The mental representation of objects and forms. In B. de Gelder (Ed.), Knowledge and 
representation. London : Routledge.

Olson, D.R., \& Bialystok, E. 1983 Spatial cognition: The structure and development of mental representations of spatial relations. Hillsdale, N. J. : Erlbaum.

Over, R. 1967 Detection and recognition measures of shape discrimination. Nature, 214, 1272.

Over, R., \& Over, S. 1967 Detection and recognition of mirror-image obliques by young children. Journal of Comparative and Physiological Psychology, 64, 467-470.

Piaget, J., \& Inhelder, B. 1948 La représentation de l'espace chez l'enfant. Paris : Presses Universitaires de France.

Quinn, P.C., \& Bomba, P.C. 1986 Evidence for a general category of oblique orientations in fourmonth-old infants. Journal of Experimental Child Psychology, 42, 345-354.

Quinn, P.C., Siqueland, E.R., \& Bomba, P.C. 1985 Delayed recognition memory for orientation by human infants. Journal of Experimental Child Psychology, 40, 293-303.

Rose, D., \& Blakemore, C. 1974 An analysis of orientation selectivity in the cat's visual cortex. Experimental Brain Research, 20, 1-17.

Rudel, R.G. 1982 The oblique mystique : A slant on the development of spatial coordinates. In M. Potegal (Ed.), Spatial abilities : Development and physiological foundations. New York : Academic.
Rudel, R.G., \& Teuber, H.L. 1963 Discrimination of direction of line in children. Journal of Comparative and Physiological Psychology, 56, 892 -898 .

Schaffer, H.R. 1974 Orientation perception in children. Nature, 252, 222-223.

Strauss, H., \& Lewin, I. 1981 A comparative study of concept formation: A conceptual analysis. Genetic Psychology Monographs, 103, 169-219.

Sutherland, N.S. 1957 Visual discrimination of orientation by octopus. British Journal of Psycho$\log y, 48,55-71$.

Sutherland, N.S. 1958 Visual discrimination of the orientation of rectangles by octopus vulgaris Lamark. Journal of Comparative and Physiological Psychology, 51, 452-458.

Sutherland, N.S. 1960 Visual discrimination of orientation by octopus : Mirror images. British Journal of Psychology, 51, 9-18.

田中敏隆 1966 図形認知の発達心理学 講談社

Thompson, G.B. 1975 Discrimination of mirrorimage shapes by young children. Journal of Experimental Child Psychology, 19, 165-176.

Weiner, K., \& Kagan, J. 1976 Infants' reaction to changes in orientation of figure and frame. Perception, 5, 25-28.

Williamson, A.M., \& McKenzie, B.E. 1979 Children's discrimination of oblique lines. Journal of Experimental Child Psychology, 27, 533-543.

(1987年11月24日受稿) 